\title{
ASUHAN KEPERAWATAN PADA Nn. G.B DAN Tn.M.B.A YANG MENGALAMI HIV/AIDS DENGAN MASALAH PERUBAHAN MEMBRAN MUKOSA ORAL DI RUANG MELATI DAN FLAMBOYAN RSUD Mgr. GABRIEL MANEK, SVD ATAMBUA
}

\author{
ABSTRAK \\ Arny Munika Manafe ${ }^{1,2)}$, Maria Fatimah W. A. Fouk ${ }^{1)}$, Melkianus Ratu ${ }^{1)}$ \\ 1) Prodi Keperawatan Universitas Timor Kampus Atambua, Jl. Wehor Kabuna Haliwen \\ Atambua Nusa Tenggara Timur. Post: 85711. Phone: 081246539171. Email: \\ arnymanafe04@gmail.com \\ 2) Rumah Sakit Umum Daerah Mgr. Gabriel Manek, SVD Atambua Jl. Dr. Soetomo No. 2, \\ Atambua, Nusa Tenggara Timur
}

\begin{abstract}
Latar belakang : Virus yang di kenal sebagai Human T Lymphotropic Virus Type III ( HTLV III ) atau sekarang yang lasim di sebut Human Immunodeficiency Virus ( HIV ). HIV dapat berkembang lebih lanjut menjadi Acquired Immunodeficiency Syndrome (AIDS). Acquire Immunodefiency Sydrom (AIDS adalah kumpulan gejala penyakit akibat menurunnya sistem kekebalan tubuh oleh virus. Tujuan : Mahasiswa mampu memberikan tindakan bagaiamana perawatan pada pasien HIV/AIDS dengan Perubahan Membran Mukosa Oral yang meliputi pengkajian, diagnosa keperawatan, perencanaan, pelaksanan dan evaluasi. Metode penelitian: Studi kasus yaitu studi yang mengekspolarasikan suatu masalah asuhan keperawatan pada Nn.G.B dan Tn. M.B.A yang mengalami HIV/AIDS dengan perubahan membran mukosa oral. Hasil: Setelah diberikan Asuhan keperawatan pada Nn. G.B dan Tn. M.B.A dengan perubahan membran mukosa oralyang sudah teratasi. Kesimpulan : Berdasarkan pembahasan pada bab IV terdahulu maka penulis mengambil kesimpulan dan saran pada Nn.G.B dan Tn.M.B.A dengan proses keperawatan yang terdiri dari Pengkajian, Diagnosa keperawatan, Perencanaan, Pelaksanaan dan Evaluasi masalah teratasi.
\end{abstract}

Kata kunci : Asuhan keperawatan, HIV/AIDS, Perubahan Membran Mukosa Oral.

\section{LATAR BELAKANG}

Virus yang dikenal sebagai Human $T$ Lymphotropic Virus Type III (HTLV III) atau lazim disebut Human Immunodeficiency Virus (HIV). Human artinya manusia bukan binatang, tumbuhan, atau serangga; Immuno artinya mengacu pada sistem immun, organ atau sel yang melawan terhadap penyakit dan infeksi; Deficiency berarti sistem imun yang mengalami kerusakan dan tidak dapat berfungsi dengan tepat untuk melawan infeksi atau penyakit di dalam tubuh dengan baik;Virus adalah mikroba yang amat sangat kecil yang bila masuk ke dalam tubuh dapat menyebabkan penyakit (Maubilli dkk, 2008). Jadi HIV merupakan virus yang mampu menghancurkan sel - sel CD4 yang berfungsi melawan infeksi pada sistem kekebalan tubuh. HIV dapat berkembang lebih lanjut menjadi Acquired Immunodeficiency Syndrome (AIDS) (Anggana, 2016). AIDS berasal dari kata Acquired yang artinya didapat atau bukan penyakit keturunan; Immune, berarti kekebalan tubuh, Deficiency atau kekurangan dan Syndrome yang berarti kumpulan gejala - gajala penyakit. Jadi dari kata - kata tersebut dapat diartikan bahwa Acquired Immunodefiency Sydrom (AIDS) adalah kumpulan gejala penyakit akibat menurunnya sistem kekebalan tubuh oleh virus (Dinah, 2003). Penderita HIV/AIDS dapatdigambarkan sebagai fenomena gunung es, artinya jumlah penderita HIV/AIDS yang dilaporkan lebih kecil dari jumlah penduduk (Maubilli dkk, 2008).

Menurut World Health Organization (WHO) sampai Oktober 2014 melaporkan jumlah penderita HIV/AIDS meningkat mencapai 33,4 juta orang. Di Indonesia kasus pertama HIV/AIDS ditemukan pada tahun 1987 di Bali, peyebaran HIV meningkat di Indonesia setelah tahun 1995.Berdasarkan data Kementerian Kesehatan sampai dengan 2017 HIV/AIDS sebanyak 268.185 orang serta penderita yang meninggal dunia sebanyak 1.146 orang. (Scince, 2017 ). Peningkatkan penderita HIV/AIDS saat ini diikuti dengan peningkatan pengetahuan perawat dan keluarga yang merawat penderta HIV/AIDS (Agung, 2003). Berdasarkan laporan statistik kasus HIV/AIDS sendiri dilaporkan berdasarkan Propinsi, yaitu di Propinsi Nusa Tenggara Timur terdapat 4.056 orang. Jumlah yang telah meninggal dunia 531 orang (Scince, 2017). Kasus pertama HIV/AIDS di Kabupaten Belu ditemukan pada tanggal 30 Agustus 2004. Ketika dilaporkan bahwa ada seorang pekerja seks komersial (PSK) di Atambua terinfeksi HIV. Pada akhir tahun 
2004 kasus HIV di Kabupaten Belu meningkat menjadi 15 orang. Pada tahun 2005 meningkat menjadi 23 orang.Hingga tahun 2017 terdapat kasus HIV /AIDS menjadi 1073 kasus (KPA, 2017). Sedangkan di RSUD Mgr. Gabriel Manek, SVD Atambua data tiga tahun terakhir adalah pada tahun 2014 sebanyak 187 kasus, tahun 2015 sebanyak 21 kasus, tahun 2016 sebanyak 187 kasus. Dari tahun ke tahun kasus HIV/AIDS terus meningkat hingga tahun 2017 sebanyak 395 kasus.

HIV/AIDS dapat berdampak pada aspek psikologis dan menimbulkan berbagai penyakit (Sari, 2017). Sebagian besar penderita HIV/AIDS sangat tertutup (Fauk et al., 2018). Penyakit ini umumnya terjadi bervariasi mulai dari ringan hingga menunjukan Infeksi penyerta (Infeksi opurtunistik). Sebagian besar penderita terkena pada saat tertentu dan jenisnya serta keparahannya tergantung pada tingginya hitung CD4 (Maubilli dkk, 2005). Berkembangnya virus HIV menjadi AIDS membutuhkan waktu 2 - 15 tahun tergantung individu masing - masing, infeksi oportunistik merupakan penyebab utama morbiditas dan mortalitas. HIV berkembang lebih lanjut menjadi AIDS menunjukan lemahnya kekebalan tubuh yang sering berwujud infeksi ikutan (infeksi oportunistik). Ketika pertama kali terinfeksi virus HIV (HIV primer) maka jumlah limfosit dan $\mathrm{CD}^{+}$dalam darah akan menurun dengan cepat ,akhirnya individu akan mudah/rentan terinfeksi opurtunistik seperti terjadinya sarkoma karposis dan lesi oral. Lesi oral atau candidiasis oral pada umumnya merupakan salah satu pertanda utama terjadinya penurunan $\mathrm{CD}^{+}$hingga mencapai < 500/4 Unordered List (UL). Candidiasis merupakan infeksi opurtunistik yang sangat umum pada orang yang terinfeksi HIV, infeksi ini disebabkan oleh sejenis jamur yang disebut candida albicans. Infeksi ini disebut thrush dan apabila menyebar dalam tenggorokan disebut esophagitis, yang tampak gumpalan putih atau bercak putih pada rongga mulut. Adanya lesi oral mengakibatkan Perubahan Membran Mukosa Oral (Nursalam, 2013).

Penatalaksanaan pasien HIV/AIDS dengan masalah Perubahan Membran Mukosa Oral ada dua cara yaitu penatalaksanan secara farmakologik dan penatalaksanan non farmakologik. Penatalaksanaan secara farmakologik adalah dengan terapi Nistatin tunggal, Nistatin Kombinasi, dan Flukonasol. Sedangkan terapi secara non farmakologik adalah berikan perawatan oral setiap hari dan setelah makan, cuci lesi oral dengan mengunakan hidrogen atau larutan soda, rencanakan diet untuk menghindari garam, pedas, dan makan/minuman asam, motivasi pemasukan oral (Siregar, 2015).

Berdasarkan latar balakang tersebut diatas penulis tertarik untuk melakukan studi kasus dengan Asuhan Keperawatan pada pasien HIV/AIDS dengan Perubahan Membran Mukosa Oral di ruang Rawat Inap RSUD Mgr Gabriel Manek, SVD Atambua.

\section{METODE}

Penelitian ini merupakan suatu studi kasus dalam bentuk asuhan keperawatan dengan tujuan untuk umum Melaksanakan Asuhan Keperawatan Klien HIV/AIDS dengan Perubahan Membran Mukosa Oral di ruang Rawat Inap RSUD Mgr Gabriel Manek SVD, Atambua, dan tujuan khusus Melaksanakan pengkajian keperawatan, diagnosa keperawatan, intervensi keperawatan, implementasi keperawatan serta evaluasi keperawatan pada klien yang mengalami HIV/AIDS dengan Perubahan Membran Mukosa Oral di ruang Rawat Inap RSUD Mgr. Gabriel Manek, SVD Atambua. Studi kasus ini adalah mengekspolarasi masalah Asuhan keperawatan pada klien yang mengalami HIV/AIDS dengan Perubahan Membran Mukosa Oral di Ruang Rawat Inap RSUD Mgr Gabriel Manek SVD, Atambua. Partisipan dalam penelitian ini adalah 2 orang pasien yang dirawat dengan diagnosa medis HIV/AIDS dan masalah keperawatan yang muncul berupa Perubahan Membran Mukosa Oral. Pengumpulan data menggunakan format pengkajian yang sudah baku dengan cara: 1) Wawancara (hasil anmesis berisi tentang identitas, keluhan utama, riwayat penyakit sekarang, dahulu, keluarg dll). Sumber data dari klien, keluarga, perawat dan lainnya); 2) Observasi dan pemeriksaan fisik (dengan pendekatan IPPA: Inspeksi, Palpasi, Perkusi, Auskultasi) pada sistem tubuh klien; dan 3) Studi dokumen dan angket (hasil dari pemeriksaan diagnosis dan data lain yang relevan). 


\section{HASIL DAN PEMBAHASAN}

Pelaksanan penelitian sejak tanggal 21-26 Januari 2019 dilakukan proses keperawatan tentang HIV/AIDS dengan masalah Keperawatan Perubahan Membran Mukosa Oral di Ruang Rawat Nginap RSUD Mgr. Gabriel Manek, SVD Atambua yang akan diuraikan sebagai berikut :

\section{Pengkajian}

Pengkajian perawatan dilakukan terhadap 2 orang klien yang mengalami sakit yang sama yaitu: Klien 1) Nn. G.B, umur 31 tahun, pendidikan SMA, pekerjaan pegawai Diler (Sales), belum menikah, suku Dawan, masuk rumah sakit 21 Januari 2019, informasi diperoleh dari klien dan orang tuanya. Dirawat dengan diagnosa HIV/AIDS. Klien 2) Tn. M.B.A, umur 30 tahun, pendidikan SMA, pekerjaan nelayan, sudah menikah, suku Tetun, masuk rumah sakit 21 Januari 209 dengan diagnosa HIV/AIDS. Informasi diperoleh dari istrinya.

\section{Tabel 1 Riwayat Penyakit}

\begin{tabular}{|c|c|c|}
\hline Riwayat Penyakit & Klien 1 & Klien 2 \\
\hline Keluhan Utama & $\begin{array}{l}\text { Pasien mengatakan Lemas, mencret selama } 7 \text { hari, mual - muntah dan tidak ada napsu makan } \\
\text { sejak tanggal } 14 \text { Januari } 2019 .\end{array}$ & $\begin{array}{l}\text { Pasien mengatakan batuk kering kurang lebih satu minggu,deman turun naik, kepala sakit } \\
\text { lemas, mual - muntah, tidak ada napsu makan, pasien sementara OAT dan Minum ARV }\end{array}$ \\
\hline Keluhan Saat dikaji & $\begin{array}{l}\text { Pasien mengatakan tidak ada napsu makan, ada luka didalam mulut dan sakit saat } \\
\text { menelan,Lidah terasa tebal, setiap kali makan mual - muntah,BAB : } 6 \text { x/hari, warna kuning } \\
\text { encer. }\end{array}$ & Pasien mengatakan tidak ada napsu makan, mual - muntah, lidah tersa tebal,nyeri telan. \\
\hline Riwayat Penyakit Sekarang & $\begin{array}{l}\text { Pasien mengatakan di rumah mencret selama } 7 \text { hari, mual - muntah, tidak ada napsu makn } \\
\text { sehingga pada tanggal } 21 \text { Januari } 2019 \text { jam } 23.00 \text { wita Pasien diantar oleh keluarga ke RSUD } \\
\text { Mgr.Gabriel Manek Atambua dengan keluhan mencret selama } 7 \text { hari, napsu makan tidak } \\
\text { ada,nyeri telan, lidah terasa tebal. }\end{array}$ & $\begin{array}{l}\text { Pasien mengatakan batuk kering kurang lebih satu minggu di rumah, deman turun naik, } \\
\text { kepala sakit, tidak ada napsu makan, sehinga keluarga memutuskan membawa pasien ke } \\
\text { RSUD Mgr.Gabriel Manek, SVD Atambua. }\end{array}$ \\
\hline Riwayat Penyakit dahulu & $\begin{array}{l}\text { Pasien mengatakan sebelumnya pernah dirawat di Klinik Swaata Kiupukan dengan keluhan } \\
\text { Batuk darah dan pasien post OAT tuntas. Tahun } 2016 \text { pasien berkenalan dengan seorang pria, } \\
\text { yang selanjutnya menjadi pacar pasien. Pasien mengatakan pernah melakukan hubungan seks } \\
\text { dengan pacarnya. Tahun } 2017 \text { pacarnya meninggal dunia, kematiannya tidak diketahui apa } \\
\text { penyebabnya? Namun kemungkinan akibat penyakit mematikan ini atau HIV/AIDS. Sejak } \\
\text { kematian pacarnya pasien tidak pernah pacaran lagi dan selama ini pasien mengalami mencret, } \\
\text { dan batuk selalu membeli obat warung dan sembuh. }\end{array}$ & $\begin{array}{l}\text { Pasien mengatakan sebelumnya pernah dirawat di RSUD Mgr. Gabriel Manek,SVD dengan } \\
\text { Keluhan yang sama. Dan pasien sementara terapi OAT dan ARV. Pasien mengatakan pada } \\
\text { tahun } 2013 \text { sampai dengan tahun } 2014 \text { bekerja di Timor Leste sebagai sopir. Selama di Timor } \\
\text { Leste pasien sering melakukan hubungan seks dengan beberapa wanita penghibur. Tahun } \\
2017 \text { pasien kembali ke Atapupu dan menikah dengan istrinya.Selama menikah dengan } \\
\text { istrinya pasien sudah sering sakit - sakit ( batuk, mencret), hingga Desember } 2018 \text { keluhan } \\
\text { pasien semakin parah dan oleh keluarga pasien dibawa ke RSUD Mgr.Gabriel Manek, SVD } \\
\text { Atambua.Sejak itu pasien mengetahui menderita HIV/AIDS. }\end{array}$ \\
\hline
\end{tabular}

1) Perubahan Pola Kesehatan

Tabel 2 Perubahan Pola kesehatan

\begin{tabular}{|c|c|c|}
\hline Pola kesehatan & Klien 1 & Klien 2 \\
\hline $\begin{array}{l}\text { Pola Manajemen } \\
\text { Kesehatan }\end{array}$ & $\begin{array}{l}\text { Sebelum sakit : Pasien tidak mengetahui cara penularan penyakit sehingga melakukan seks bebas. } \\
\text { Saat sakit : Pasien mengatakan kesehatan itu sangat penting dan pasien menerimah pengobatan } \\
\text { untuk kesembuhannya }\end{array}$ & $\begin{array}{l}\text { Sebelum sakit : Pasien tidak mengatahui penularan penyakit sehingga melakukan seks bebas } \\
\text { Saat sakit : Pasien mengatakan kesehatan itu sangat penting dan utama }\end{array}$ \\
\hline
\end{tabular}




\begin{tabular}{|c|c|}
\hline Pola Nutrisi & $\begin{array}{l}\text { Sebelum sakit: Pasien mengatakan makan } 3 \mathrm{x} \text { sehari, dengan porsi yang disediakan selalu } \\
\text { dihabiskan, jenis makanan : Nasi, sayur, tempe, tahu, ikan dan daging (Kadang - kadang).Minum } \\
\text { air putih kurang lebih } 6 \text { - } 7 \text { gelas perhari } \\
\text { Saat sakit : Pasien mengatakan tidak ada napsu makan, pola makan } 3 x \text { sehari dengan porsi makan } \\
\text { tidak dihabiskan, setiap kali makan pasien hanya bisa menghabiskan kurang lebih } 4-5 \text { sendok saja, } \\
\text { nyeri telan, terasa mual - muntah jenis makan bubur, sayur, telur. Minum } 1-2 \text { gelas sehari }\end{array}$ \\
\hline Pola eliminasi & $\begin{array}{l}\text { Sebelum sakit : Pasien mengatakn BAB kurang lebih 1-2 x sehari, konsistensi lembek, warna } \\
\text { kuning, bau kas feses. BAK kurang lebih 4-5 x sehari bau kas urine amoniak. } \\
\text { Saat sakit : Saat dikaji pasien belum BAB: } 6 \text { x/hari, encer bau kas } \\
\text { BAK kurang 3- } 4 \text { x per hari, warna kuning, bau kas urine amoniak. }\end{array}$ \\
\hline Pola aktivitas & $\begin{array}{l}\text { Sebelum sakit : Pasien mengatakan sering melakukan kegiatan sehari- hari seperti biasa secara } \\
\text { mandiri. } \\
\text { Saat sakit : Pasien mengatakan tidak bisa melakukan aktivitas sendiri. Semua aktivitas (makan, } \\
\text { minum, BAB, BAK, mandi) dibantu oleh keluarga karena kondisinya yang sangat lemah dan } \\
\text { terbaring ditempat tidur. }\end{array}$ \\
\hline Pola istirahat tidur & $\begin{array}{l}\text { Sebelum sakit : Pasien mengatakan jarang tidur siang karena ia bekerja dari jam } 07.30 \text { wita s/d jam } \\
17.30 \text { wita, tidur malma kurang lebih } 6-7 \text { jam. } \\
\text { Saat sakit : Pasien mengatakan tidur tidak teratur karena sering terbangun saat BAB, ppasien tidur } \\
\text { minimal } 4-5 \text { jam. }\end{array}$ \\
\hline $\begin{array}{l}\text { Pola kognitif dan } \\
\text { persepsi sensori }\end{array}$ & Pasien mengatakan belum mengetahui penyakit yang dideritanya. \\
\hline Pola konsep diri & $\begin{array}{l}\text { Gambaran diri : Pasien mengatakan dirinya tidak sekuat dulu dan berharap agar ia bisa cepat } \\
\text { sembuh dan keluar dari rumah sakit. } \\
\text { Ideal diri : Pasien berharap ingin cepat sembuh dari penyakitnya. } \\
\text { Harga diri : Pasien mengatakan dirinya sangat disayangi oleh ibunya. } \\
\text { Peran diri : Pasien mengatakan ia merupakan anak keempat dari empat bersaudara dan sampai } \\
\text { pada saat ini masih tinggal bersama dengan orangtuanya. Sehari - hari ia bekerja sebagai Pegawai } \\
\text { deler (sales) motor di sebuah perusahaan swasta di Kefa. } \\
\text { Identitasdiri : Pasien mengatakan ia adalah seorang perempuan yang berusia } 31 \text { tahun, dan belum } \\
\text { menikah. }\end{array}$ \\
\hline Pola hubungan peran & $\begin{array}{l}\text { Pasien mengatakan perannya sebagai anak mencari nafkah untuk membantu ibunya yang seorang } \\
\text { janda, sangat terganggu karena penyakitnya. Dan hubungan dengan keluarga terjalin baik. }\end{array}$ \\
\hline $\begin{array}{l}\text { Pola fungsi seksual } \\
\text { dan fungsi seksualitas }\end{array}$ & $\begin{array}{l}\text { Sebelum sakit: Pasien pernah melakukan seks bebas tanpa mengunakan kondom. } \\
\text { Saat sakit : Pasien mengatakan tidak pernah melakukan seks }\end{array}$ \\
\hline $\begin{array}{l}\text { Poa mekanisme } \\
\text { Koping }\end{array}$ & Pasien mengatakan takut dengan penyakit yang dideritanya. \\
\hline $\begin{array}{l}\text { Pola nilai dan } \\
\text { kepercayaan }\end{array}$ & $\begin{array}{l}\text { Pasien mengatakan beragama Katholik dan percaya kepada Tuhan Yesus akan memberikan } \\
\text { Kesembuhan, pasien juga adalah anggota OMK di Paroki Nasleu. }\end{array}$ \\
\hline
\end{tabular}

Sebelum sakit : Pasien mengatakan 3x sehari dengan porsi makan yang disediakan selal dihabiska . Jenis makan : Nasi, sayur, Ikan, daging (kadang - kadang). Minum air putih kurang lebih 5 -6 gelas perhar

Saat sakit : Pasien mengatakan $3 \mathrm{x}$ sehari tetapi dengan porsi makan yang disediakan tidak dihabiskan, makan kurang 4- 5 sendok, nyeri telan. Jenis makanan nasi, sayur, ikan. Minum kurang lebih $1-3$ gelas sehari

Sebelum sakit : Pasien mengatakan 1- 2 x/hari, konsistensi lembek, warna kuning, bau kas eses. BAK kurang lebih 4- $5 \mathrm{x}$ perhari, warna kuning bau kas urine amoniak.

Saat sakit : Saat dikaji pasien belum BAB $: 4$ x/hari, lembek bau kas.

BAK kurang lebih 3- 4 perhari, bau kas urine amoniak.

Sebelum sakit : Pasien mengatakan sering melakukan kegiatan seperti biasa tanpa bantuan orang lain.

aat sakit : Pasien mengatakan tidak bis a melakukan aktivitas. Semua aktivitasnya dibant oleh istri dan keluarga.

Sebelum sakit : Pasien mengatakan tidur siang 3- 4 jam, tidur malam 3- 4 jam.

Saat sakit : Pasien mengatakan tidur siang 1- 2 jam, tidur malam 2- 3 jam saja, karena sering terbangun karena batuk pada malam har.

Pasien mengatakan mengetahui penyakit yang diderita dan ingin sembuh.

Gambaran diri : Pasien mengatakan dirinya tidak sekuat dulu dan selalu berharap agar cepat embuh.

deal diri : Pasien berharap cepat sembuh dari penyakit ini.

Harga diri : Pasien mengatakan tidak malu dengan penyakit yang diderita sekarang ini.

Peran diri : Pasien mengatakan ia adalah anak pertama dari tiga bersaudara, seorang suami

dari seorang istri dan seorang ayah dari seorang anak yang berusia 2 tahun. Sehari -hari ia

bekerja sebagai seorang nelayan.

Identitas diri : Pasien mengatakan dia adalah seorang laki - laki yang berusia 30 tahun, dan sudah menikah, memiliki seoarang anak laki - laki yang berusia 2 tahun.

Pasien mengatakan perannya sebagai sorang kepala keluarga mencari nafkah, sangat tergannggu karena penyakitnya. Dan hubungan dengan keluarga dan tetangga terjalin bik. Sebelum sakit : Pasien mengatakan sering melakukan hubungan seks bebas dengan beberapa wanita penghibur tanpa mengunakan kondom.

aat sakit : Pasien mengatakan tidak melakukan hubungan seks dengan istrinya saja. Pasien mengatakan bahwa ia yakin kalau penyakit yang dialami akan sembuh setelah mendapatkan pengobatan.

Pasien mengatakan ia beragama Katholik dan percaya Tuhan Yesus akan memberikan kesembuhan bagi dirinya. 


\section{2) Pemeriksaan Fisik}

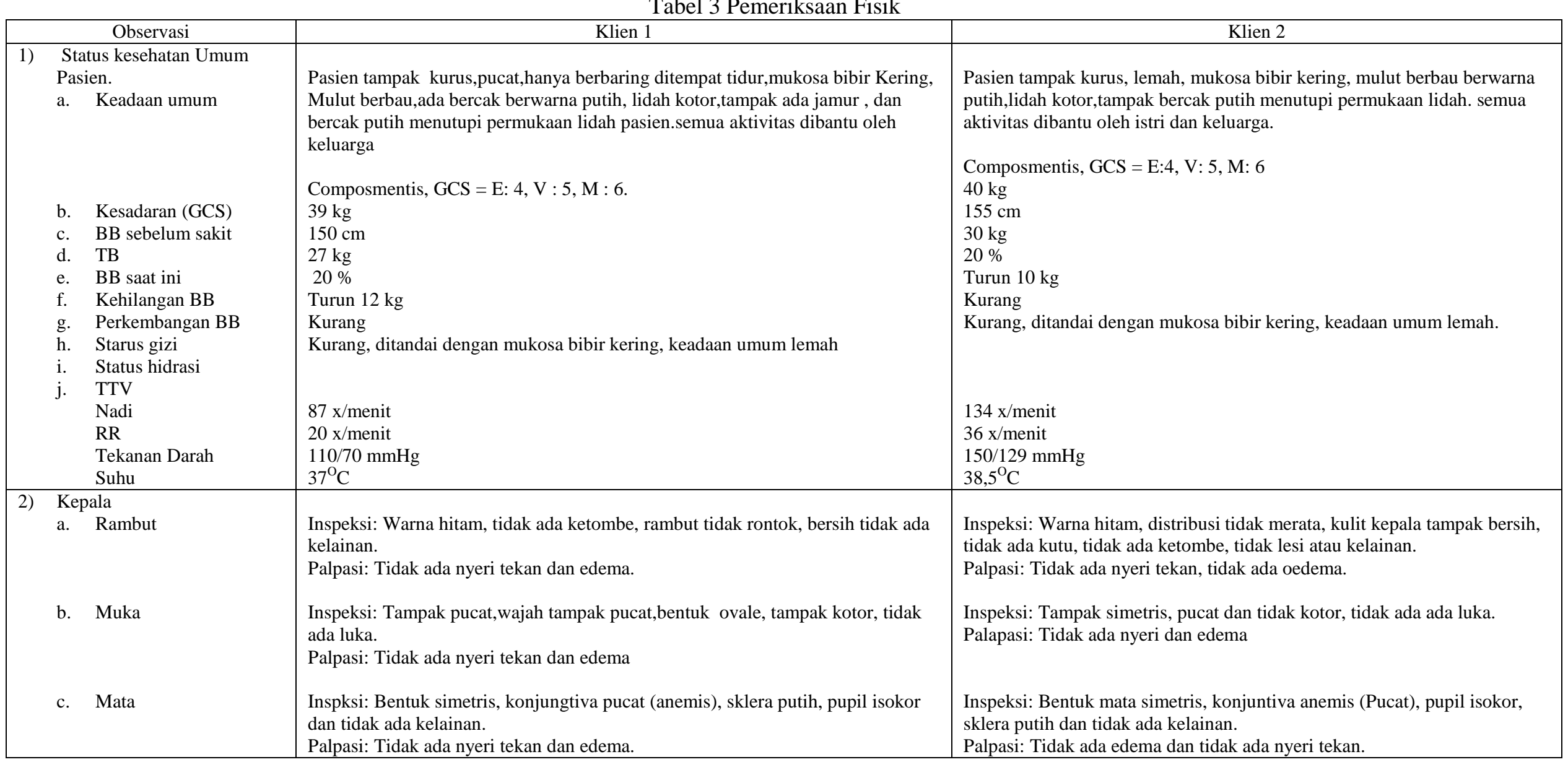

Jurnal Sahabat Keperawatan, Vol. 2; No. 2; Agustus 2020 


\begin{tabular}{|c|c|c|c|}
\hline & Hidung & $\begin{array}{l}\text { Inspeksi: Tampak simetris, bersih, tidak ada secret, tidak ada luka, tidak ada } \\
\text { pernapasan cuping hidung, dan tidak ada kelainan. } \\
\text { Palpasi: Tidak nyeri takan dan tidak ada edema. }\end{array}$ & $\begin{array}{l}\text { Inspeksi: Tampak simetris, bersih, tidak ada secret, tidak ada luka, tidak ada } \\
\text { pernapasan cuping hidung, dan tidak ada kelainan. } \\
\text { Palpasi: Tidak ada nyeri tekan dan tidak ad edema. }\end{array}$ \\
\hline e. & Mulut dan gigi & $\begin{array}{l}\text { Inspeksi: Mukosa bibir kering, berwarna putih, mulut berbau, tampak bercak } \\
\text { putih menutupi permukaan lidah sampai tenggorokan, lidah kotor. Gigi lengkap, } \\
\text { tampak kotor, dan tidak ada kelainan, tidak ada caries gigi. } \\
\text { Palpasi: Tidak ada nyeri tekan dan tidak ada edema. }\end{array}$ & $\begin{array}{l}\text { Inspeksi: Mukosa bibir kering, lidah kotor, tampak bercak putih menutupi } \\
\text { permukaan lidah sampai tenggorokan,tidak ada luka dalam mulut, mulut } \\
\text { berbau, gigi utuh, gigi kurang bersih, dan tidak ada kelainan. } \\
\text { Palpasi: Tidak ada nyeri tekan dan tidak ada edema }\end{array}$ \\
\hline f. & Telinga & $\begin{array}{l}\text { Inspeksi: Tidak ada kelainan, tampak ada serumen, tidak ada luka. } \\
\text { Palpasi: Tidak ada nyeri tekan dan tidak edema. }\end{array}$ & $\begin{array}{l}\text { Inspeksi: Tidak ada kelainan, tampak kotor, ada serumen, tidak ada luka. } \\
\text { Palpasi: Tidak ada nyeri tekan dan tidak ada edema. }\end{array}$ \\
\hline 3) & Leher & $\begin{array}{l}\text { Inspeksi: Tidak ada kelainan, tidak ada distensi vena jugularis, leher tampak } \\
\text { kotor. } \\
\text { Palpasi: Tidak ada nyeri tekan dan tidak edema. }\end{array}$ & $\begin{array}{l}\text { Inspeksi: Tidak ada kelainan, tidak ada distensi vena jugularis, leher } \\
\text { tampak kotor. } \\
\text { Palapsi: Tidaka ada nyeri tekan dan tidak ada edema. }\end{array}$ \\
\hline & Paru -paru & $\begin{array}{l}\text { Inspeksi: Tidak ada kelainan, bentuk dada simetris, tidak ada otot bantu } \\
\text { pernapasan, tidak ada retrakdasi dinding dada. } \\
\text { Palpasi: Tidak ada nyeri tekan. } \\
\text { Perkusi: Suara resonan. } \\
\text { Auskultasi : Bunyi Ronki }(++)\end{array}$ & $\begin{array}{l}\text { Inspeksi: Tidak ada kelainan, dada simetris, tidak ada otot bantu } \\
\text { pernapasan, tidak ada retraksi dinding dada. } \\
\text { Palpasi: Tidak ada nyeri tekan. } \\
\text { Perkusi: Suara resonan } \\
\text { Auskultasi: Bunyi suara Ronki }(++)\end{array}$ \\
\hline & Jantung & $\begin{array}{l}\text { Inspeksi: Ictus cordis tidak nampak. } \\
\text { Palpasi: Tidak ada pembesaran jantung, dan tidak ada nyeri tekan. } \\
\text { Auskultasi: Terdengar BJ I dan BJ } 2 \text { tunggal dan tidak ada bunyi tambahan. }\end{array}$ & $\begin{array}{l}\text { Inspeksi : Ictus cordis tidak nampak } \\
\text { Palspasi: Tidak ada pembesaran jantung, dan tidak ada nyeri tekan. } \\
\text { Auskultasi: Terdengar BJ I - BJ } 2 \text { tunggal, tidak ada ada bunyi tambahan. }\end{array}$ \\
\hline & Abdomen & $\begin{array}{l}\text { Inspeksi: Bentuk datar, mengembang saat ekspirasi dan mengempis saat } \\
\text { inspirasi, tidak ada luka, tidak ada bekas operasi, terdapat umblikus. } \\
\text { Auskultasi: Bising usus } 36 \mathrm{x} / \text { menit.hiperaktif } \\
\text { Perkusi: Timpani } \\
\text { Palapasi: ada nyeri tekan. }\end{array}$ & $\begin{array}{l}\text { Inspeksi: Bentuk datar, mengembang saat ekspirasi dan mengempis saat } \\
\text { inspirasi, tidak ada luka, tidak ada bekas operasi, terdapat umblikus. } \\
\text { Auskultasi: Bising usus } 10 \mathrm{x} / \text { menit } \\
\text { Perkusi: Timpani } \\
\text { Palpasi: Tidak ada nyeri tekan. }\end{array}$ \\
\hline & Ekstremitas & $\begin{array}{l}\text { a. Ekstermitas Atas } \\
\text { Inspeksi: Terpasang IVFD RL } 30 \text { tpm pada tangan kiri. } \\
\text { Palpasi: Akral hangat, kekuatan otot dengan skala ROM } 5 \text { aktif } \\
\text { b. Ekstermitas bawah } \\
\text { Inspeksi: Tampak ada bekas luka di betis. } \\
\text { Palpasi: Kekuatan otot dengan skala } 4 \text { ROM aktif, akral hangat. }\end{array}$ & $\begin{array}{l}\text { a. Ekstermitas Atas } \\
\text { Inpeksi: Terpasang IVFD RL } 20 \text { tpm pada tangan kanan } \\
\text { Palpasi: Akral hangat, kekuatan otot dengan skala ROM } 5 \text { aktif. } \\
\text { b. Ekstermitas bawah } \\
\text { Tampak simetris, tidak ada bekas luka. } \\
\text { Palpasi: Kekuatan otot dengan skala } 5 \text { ROM aktif }\end{array}$ \\
\hline
\end{tabular}


6. Hasil pemeriksaan penunjang

Tabel 4 Hasil pemeriksaan Penunjang

\begin{tabular}{|c|c|c|c|}
\hline \multicolumn{4}{|c|}{ Klien 1} \\
\hline \multicolumn{4}{|c|}{ Laboratorium tanggal : 21 Januari 2019} \\
\hline & \begin{tabular}{l|l} 
& RESULT \\
\end{tabular} & UNIT & NORMAL \\
\hline WBC & 7,8 & $10^{\wedge} 3 / \mathrm{UL}$ & $4,8-10,8$ \\
\hline LYM & 1,4 & $10^{\wedge} 3 / \mathrm{UL}$ & $1,0-5,0$ \\
\hline $\mathrm{MON}$ & 0,5 & $10^{\wedge} 3 / \mathrm{UL}$ & $01-1,0$ \\
\hline GRA & 2,6 & $10^{\wedge} 3 / \mathrm{Ul}$ & $2,0-8,0$ \\
\hline LYM \% & 32,2 & $\%$ & $25,0-50,0$ \\
\hline MON \% & 8,1 & $\%$ & $2,0-10,0$ \\
\hline GRA \% & 56,8 & $\%$ & $50,0-80,0$ \\
\hline $\mathrm{RBC}$ & 5,0 & $10^{\wedge} 6 / \mathrm{UL}$ & $4,2-5,4$ \\
\hline HGB & 13,7 & $\mathrm{~g} / \mathrm{dL}$ & $12-16$ \\
\hline HCT & 41,3 & $\%$ & $37-97$ \\
\hline $\mathrm{MCV}$ & 82,8 & $\mathrm{UM}^{\wedge} 3$ & $79-99$ \\
\hline $\mathrm{MCH}$ & 27,5 & $\mathrm{Pg}$ & $27-31$ \\
\hline $\mathrm{MCHC}$ & 33,2 & $\mathrm{~g} / \mathrm{dL}$ & $33-37$ \\
\hline RDW & 17,1 & +96 & $11,5-14,5$ \\
\hline PLT & 494,0 & $10^{\wedge} 3 / \mathrm{UI}$ & $150-400$ \\
\hline MPV & 8,8 & -FL & $9-13$ \\
\hline \multicolumn{4}{|c|}{ b.Kimia Klinik tanggal pemeriksaan : 22 Januari 2019} \\
\hline 1. & \multirow{2}{*}{\multicolumn{3}{|c|}{$\begin{array}{ll}\text { Kreatin Serum } & : 1,0 \mathrm{mg} / \mathrm{dl} \text { P: }(0,5-0,9 \mathrm{mg} / \mathrm{dl}) \mathrm{L}:(0,6-1,1 \mathrm{mg} / \mathrm{dl}) \\
\text { Ureum } & : 40 \mathrm{mg} / \mathrm{dl} \quad(10-50 \mathrm{mg} / \mathrm{dl})\end{array}$}} \\
\hline 2. & & & \\
\hline 3. & SGOT $: 3$ & \multicolumn{2}{|c|}{$\mathrm{P}:(<31 \mathrm{U} / \mathrm{I}) \mathrm{L}:(<37 \mathrm{U} / \mathrm{I})$} \\
\hline 4. & $\begin{array}{ll}\text { SUU1 } & : 3 \\
\text { SGPT } & : 3\end{array}$ & $\mathrm{P}:(<32 \mathrm{U} / \mathrm{I}) \mathrm{L}$ & \\
\hline
\end{tabular}

\begin{tabular}{|c|c|}
\hline $\begin{array}{l}\text { C.Serologi } \\
\text { HBSAG } \\
\text { HIV }\end{array}$ & $\begin{array}{l}\text { : Negative } \\
\text { : Positife }\end{array}$ \\
\hline $\begin{array}{c}\text { d.Parasitol } \\
\text { Malaria }\end{array}$ & : Negative \\
\hline $\begin{array}{l}\text { e.Elektroli } \\
\text { Tanggal } \\
\mathrm{Na}: 1 \\
\mathrm{~K} \quad: 5 \\
\mathrm{CI}: 1\end{array}$ & $\begin{array}{cc} \\
\text { meriksaan : } 23 \text { Januari } 2019 \\
\mathrm{mmol} / \mathrm{L} \quad(135-148) \mathrm{mmol} / \mathrm{L} \\
\mathrm{mmol} / \mathrm{L} & (3,5-5,3) \mathrm{mmol} / \mathrm{L} \\
\mathrm{mmol} / \mathrm{L} & (98-106) \mathrm{mmol} / \mathrm{L}\end{array}$ \\
\hline
\end{tabular}

\begin{tabular}{|l|l|l|l|}
\hline \multicolumn{4}{|c|}{ Klien 2 } \\
\hline \multicolumn{4}{|c|}{ a. Laboratorium tanggal 23 Januari 2019} \\
\hline WBC & RESULT & UNIT & NORMAL \\
\hline LYM & $\mathbf{1 5 , 5}$ & $\mathbf{1 0}$ 3/UL & $\mathbf{4 , 8 - 1 0 , 8}$ \\
\hline MON & 1,6 & $10^{\wedge} 3 /$ UL & $1,0-5,0$ \\
\hline GRA & 0,8 & $10^{\wedge} 3 /$ UL & $01-1,0$ \\
\hline LYM\% & 13,1 & $10^{\wedge} 3 /$ Ul & $2,0-8,0$ \\
\hline MON \% & 10,6 & $\%$ & $25,0-50,0$ \\
\hline GRA \% & 5,0 & $\%$ & $2,0-10,0$ \\
\hline & $\mathbf{8 4 , 4}$ & $\mathbf{\%}$ & $\mathbf{5 0 , 0}-\mathbf{8 0 , 0}$ \\
\hline RBC & & & \\
\hline HGB & 5,08 & $10^{\wedge} 6 /$ UL & $4,2-5,4$ \\
\hline HCT & $\mathbf{1 0 , 3}$ & g/dL & $\mathbf{1 2}-\mathbf{1 6}$ \\
\hline MCV & $\mathbf{3 2 , 6}$ & $\mathbf{\%}$ & $\mathbf{3 7}-\mathbf{9 7}$ \\
\hline MCH & $\mathbf{6 4 , 2}$ & $\mathbf{U M} \mathbf{3}$ & $\mathbf{7 9 - 9 9}$ \\
\hline MCHC & $\mathbf{2 0 , 3}$ & $\mathbf{P g}$ & $\mathbf{2 7}-\mathbf{3 1}$ \\
\hline RDW & 31,6 & g/dL & $33-37$ \\
\hline
\end{tabular}




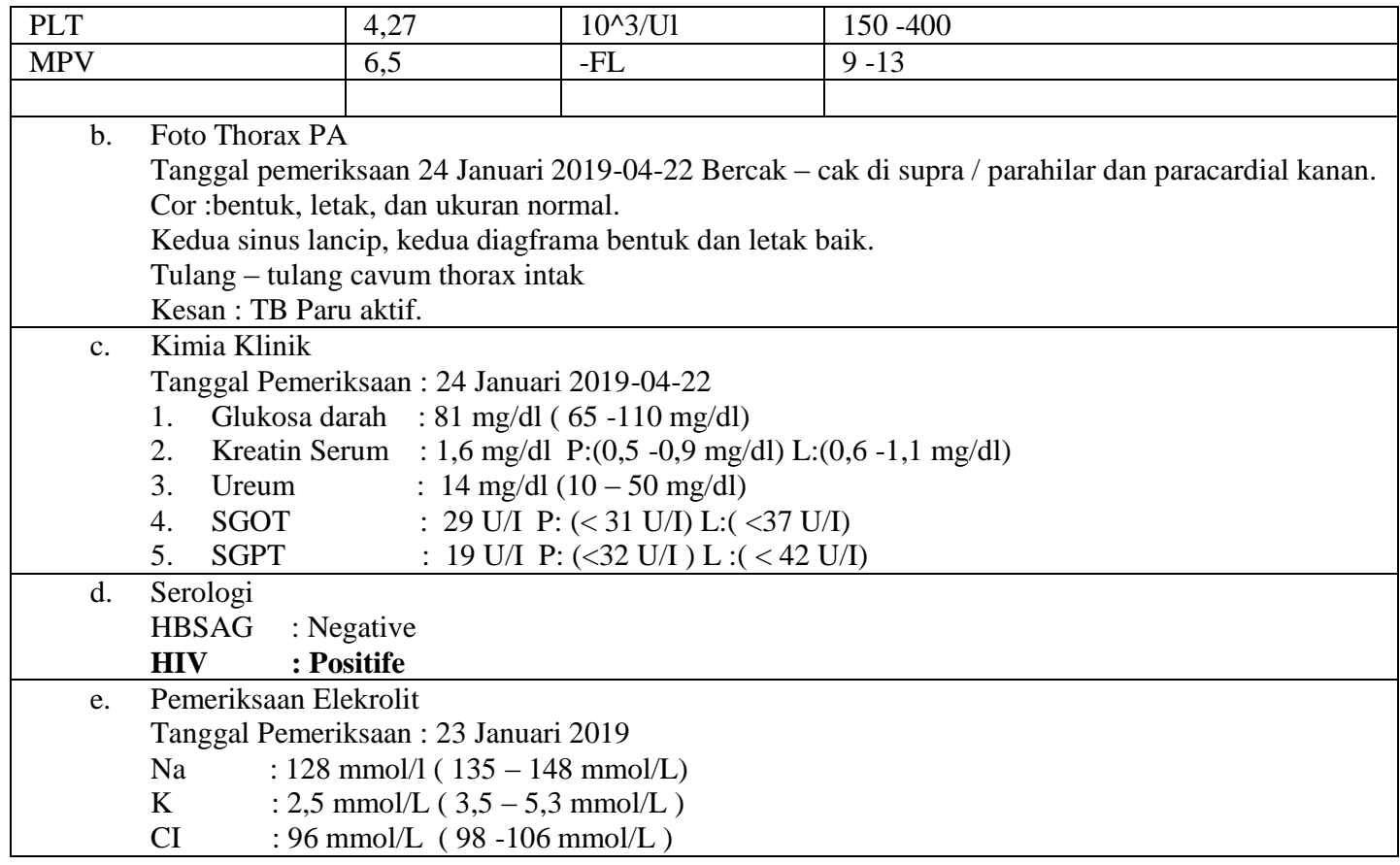

\section{Terapi ( 6 benar )}

Tabel 5 Terapi

\begin{tabular}{|c|c|c|}
\hline Terapi & Klien 1 & Klien 2 \\
\hline \multirow[b]{2}{*}{ Oral } & Senin, 21 Januari 2019 & Selasa, 22 Januari 2019 \\
\hline & $\begin{array}{l}\text { Cotrimoxazole } 2 \times 960 \mathrm{mg} \\
\text { Sanmol 3x 500mg } \\
\text { Nystatin drop 3x } 4 \text { tetes/oral }\end{array}$ & $\begin{array}{l}\text { Paracetamol } 3 \times 500 \mathrm{mg} \\
\text { Ambroxol } 3 \times 30 \mathrm{mg} \\
\text { L- bio } 2 \times 1 \text { gr. } \\
\text { Nystatin drop } 3 \times 4 \text { tetes/oral }\end{array}$ \\
\hline Parental & $\begin{array}{l}\text { IVFD RL } 30 \text { tetes/menit } \\
\text { Omeprazole } 2 \times 4 \mathrm{mg} / \mathrm{IV} \\
\text { Neurobion } 2 \times 4 \mathrm{mg} / \mathrm{IV}\end{array}$ & $\begin{array}{l}\text { IVFD RL } 20 \text { tetes/menit } \\
\text { Cefriaxone } 2 \times 1 \mathrm{gr} / \mathrm{IV} \\
\text { Ranitidin } 2 \times 50 \mathrm{mg} / \mathrm{IV}\end{array}$ \\
\hline \multirow[b]{2}{*}{ Oral } & Selasa, 22 Januari 2019 & Rabu, 23 Januari 2019 \\
\hline & $\begin{array}{l}\text { Cotrimoxazole } 2 \text { x 960mg } \\
\text { Sanmol 3x 500 mg } \\
\text { Ketoconazole 1x 200mg } \\
\text { Nystatin drop 3x } 4 \text { tetes/oral }\end{array}$ & $\begin{array}{l}\text { Paracetamol 3x 500mg } \\
\text { Codein } 2 \times 10 \mathrm{mg} \\
\text { Cefixime } 2 \times 100 \mathrm{mg} . \\
\text { Nystatin drop } 3 \times 4 \text { tetes /oral }\end{array}$ \\
\hline Parental & $\begin{array}{l}\text { IVFD RL } 20 \text { tetes/menit } \\
\text { Omiprasole } 2 \times 4 \mathrm{mg} / \mathrm{IV} \text {. } \\
\text { Nerobion } 2 \times 4 \mathrm{mg} / \mathrm{IV} \\
\text { Cefriaxone } 2 \times 50 \mathrm{mg} / \mathrm{IV}\end{array}$ & $\begin{array}{l}\text { IVFD RL } 20 \text { tetes/menit } \\
\text { Cefiaxone } 2 \times 1 \mathrm{gr} / \mathrm{IV} \\
\text { Ranitidin } 2 \times 50 \mathrm{mg} \\
\text { Metilprednison } 1 \times 6,25 \mathrm{mg}\end{array}$ \\
\hline & Rabu, 23 Januari 2019 & Kamis, 24 Januari 2019 \\
\hline Parental & $\begin{array}{l}\text { Cotrimoxazole } 2 \text { × } 960 \mathrm{mg} \\
\text { Sanmol } 3 \text { × } 500 \mathrm{mg} \\
\text { Ketoconazole } 1 \text { × } 200 \mathrm{mg} \\
\text { Nystatin drop } 3 \text { × } 4 \text { tetes/oral } \\
\\
\text { IVFD RL } 20 \text { tetes } / \mathrm{menit} \\
\text { Cefriaxone } 2 \times 50 \mathrm{mg} / \mathrm{IV} \\
\text { Omiprasole } 2 \times 4 \mathrm{mg} / \mathrm{IV} \\
\text { Nerobion } 2 \times 4 \mathrm{mg} / \mathrm{IV} \\
\text { Kolaborasi Klinik VCT. }\end{array}$ & $\begin{array}{l}\text { Paracetamol } 3 \times 500 \mathrm{mg} \\
\text { Codein } 2 \times 10 \mathrm{mg} \\
\text { Cefixime } 2 \times 100 \mathrm{mg} . \\
\text { Nystatin drop } 3 \times 4 \text { tetes/oral } \\
\text { IVFD RL } 20 \text { tetes/menit } \\
\text { Cefriaxone } 2 \times 1 \mathrm{gr} / \mathrm{IV} \\
\text { Ranitidin } 2 \times 50 \mathrm{mg} / \mathrm{IV} \\
\text { Metilprednison } 1 \text { × } 6,25 \mathrm{mg}\end{array}$ \\
\hline
\end{tabular}


2. Analisa Data dan Diagnosa Keperawatan

Tabel 6 Analisa Data dan Diagnosa Keperawatan

\begin{tabular}{|c|c|c|}
\hline Analisa Data & Etiologi & Masalah \\
\hline \multicolumn{3}{|c|}{ Klien 1} \\
\hline $\begin{array}{l}\text { DS } \\
\text { Pasien mengatakan tidak ada napsu makan, ada luka } \\
\text { didalam mulut dan sakit saat menelan,Lidah terasa tebal, } \\
\text { setiap kali makan mual - muntah. } \\
\text { DO. } \\
\text { Pasen lemah,pucat,hanya berbaring ditempat tidur,mukosa } \\
\text { bibir Kering, Mulut berbau,ada bercak berwarna putih, } \\
\text { lidah kotor,tampak ada jamur, dan bercak putih menutupi } \\
\text { permukaan lidah pasien. } \\
\text { Terpasang IVFD } 30 \text { tetes/menit } \\
\text { Nadi } 87 \text { x/menit } \\
\text { RR } \quad 20 \text { x/menit } \\
\text { Tekanan Darah } 110 / 70 \text { mmHg } \\
\text { Suhu } 37^{\circ} \text { C. } \\
\text { Hasil Laboratorium tanggal } 22 \text { Januari } 2019 \text { Pemeriksaan } \\
\text { Serologi } \\
\text { HIV : Positife. } \\
\text { WBC : } 7,8\end{array}$ & $\begin{array}{l}\text { Hubungan seks bebas tanpa } \\
\text { Vondom } \\
\text { Virus HIV masuk kedalam } \\
\text { Infeksi berbagai jaringan } \\
\text { Destruksi jaringan dan CD4+ } \\
\text { menjurun } \\
\text { Infeksi Oputunistik } \\
\text { Candidiasis, kriptokokus, } \\
\text { histoplamosis dimulut } \\
\text { Candidiasis oral } \\
\text { Defist imunologi sekunder } \\
\text { akibat candidiasis }\end{array}$ & $\begin{array}{l}\text { Perubahan Membran } \\
\text { Mukosa Oral }\end{array}$ \\
\hline \multicolumn{3}{|c|}{ Klien 2} \\
\hline $\begin{array}{l}\text { DS. } \\
\text { Pasien mengatakan tidak ada napsu makan, mual - muntah, } \\
\text { lidah tersa tebal } \\
\text { DO. } \\
\text { Pasien lemah, mukosa bibir kering, mulut berbau berwarna } \\
\text { putih,lidah kotor,tampak bercak purih menutupi permukaan } \\
\text { lidah. Terpasang IVFD RL } 20 \text { tetes /menit } \\
\text { Tanda - tanda vital : } \\
\text { Nadi : } 134 \mathrm{x} / \text { menit } \\
\text { RR :36 x/menit } \\
\text { Tekanan Darah: } 150 / 129 \mathrm{mmHg} \\
\text { Suhu : } 38,5^{\circ} \text { C. } \\
\text { Terpasang IFVFD RL } 20 \text { tetes/menit. } \\
\text { Hasil laboratorium tanggal } 23 \text { Januari } 2019 \text {. } \\
\text { HIV : Positife. } \\
\text { WBC : } 15,5\end{array}$ & $\begin{array}{l}\text { Hubungan seks bebas tanpa } \\
\text { kirus HIV masuk kedalam } \\
\text { kupuh } \\
\text { Menyerang CD4 dan } \\
\text { Destruksi jaringan dan CD4+ } \\
\text { menurun } \\
\text { Infeksi Oputunistik } \\
\text { Candidiasis, kriptokokus, } \\
\text { histoplamosis dimulut } \\
\text { Candidiasis oral } \\
\text { Defist imundlogi sekunder } \\
\text { akibat candidiasis. }\end{array}$ & $\begin{array}{l}\text { Perubahan Membran } \\
\text { Mukosa Oral }\end{array}$ \\
\hline Diagnosa Keperawatan sama untuk kedua pasien, yaitu & \multicolumn{2}{|c|}{$\begin{array}{l}\text { Perubahan Membran Mukosa oral berhubungan } \\
\text { dengan defisit imunologi sekunder akibat candidiasis } \\
\text { oral }\end{array}$} \\
\hline
\end{tabular}




\section{Perencanaan}

\begin{tabular}{|l|}
\hline \multicolumn{1}{|c|}{ Diagnosa keperawatan (Tujuan dan kriteria hasil) } \\
\hline Perubahan Membran Mukosa oral berhubungan dengan defisit imunologi \\
sekunder akibat candidiasis oral. \\
Goal : membran mukosa oral kembali utuh selama dalam perawatan $3 \times 24$ jam. \\
Objektif: \\
Setelah dilakukan tindakan keperawatan selama $3 \times 24$ jam diharapkan perubahan \\
membran mukosa oral kembali utuh dengan kriteria hasil : \\
1. Bercak - cak putih dalam mulut dan lidah berkurang. \\
2. Mulut tidak berbau. \\
3. Membran mukosa oral merah muda dan lembab \\
4. Jamur dalam mulut berkurang. \\
5. TTV dalam batas normal. \\
TD : $110-130 / 70$ mmHg. \\
Nadi: $60-100 \times /$ menit \\
Suhu : $36,5^{\circ} \mathrm{C}-37,5^{\circ} \mathrm{C}$ \\
RR : $16-24 \mathrm{x} / \mathrm{menit}$ \\
\end{tabular}

Perubahan Membran Mukosa oral berhubungan dengan defisit imunologi

sekunder akibat candidiasis oral.

Goal : membran mukosa oral kembali utuh selama dalam perawatan $3 \times 24$ jam.

Objektif:

Setelah dilakukan tindakan keperawatan selama 3 x 24 jam diharapkan perubahan

membran mukosa oral kembali utuh dengan kriteria hasil :

1. Bercak - cak putih dalam mulut dan lidah berkurang.

Mulut tidak berbau.

2. Membran mukosa oral merah muda dan lembab

3. Jamur dalam mulut berkurang.

4. TTV dalam batas normal.

TD : $110-130 / 70 \mathrm{mmHg}$.

Nadi: $60-100 \mathrm{x} / \mathrm{menit}$

RR : $16-24 \mathrm{x} /$ menit
Tabel 7 Perencanaan
Intervensi

Klien 1 Kaji membran mukosa atau catat seluruh lesi oral.Perhatikan
Kaji membran mukosa atau catat seluruh lesi oral.Perhaik
keluhan nyeri,bengkak, sulit mengunyah atau menelan.

2. Berikan perawatan oral setiap hari dan setelah makan, gunakan sikat gigi yang halus.

3. Motivasi pemasukan oral sedikit $2.500 \mathrm{ml} / \mathrm{hari}$

. Anjurkan mengunyah permen karet atau permen yang tidak mengandung gula.

5. Anjurkan pasien untuk menghindari garam, pedas, asam.

Tawarkan makanan yang dingin dan segar.

6. Motivasi pasien agar tidak merokok

7. Kolaborasi obat-obatan sesuai instruksi dokter, antijamur, antimikroba

\section{Klien 2}

1. Kaji membran mukosa atau catat seluruh lesi oral. Perhatikan

keluhan nyeri, bengkak, sulit mengunyah atau menelan.

Berikan perawatan oral setiap hari dan setelah makan

gunakan sikat gigi yang halus.

3. Motivasi pemasukan oral sedikit $2.500 \mathrm{ml} / \mathrm{hari}$.

4. Anjurkan mengunyah permen karet atau permen yang tidak mengandung gula.

5. Anjurkan pasien untuk menghindari garam, pedas, asam.

Tawarkan makanan yang dingin dan segar.

6. Motivasi pasien tidak merokok.

7. Kolaborasi obat - obatan sesuai instruksi

dokter,antijamur,antimikroba
1. Edema, lesi mukosa oral dan tenggorok kering

menyebabakan rasa sakit dan sulit mengunyah atau menelan

2. Mengurangi ras tidak nyaman, meningkatkan rasa sehat dan mencegah pembentukan asam yang dikaitkan denganpartikel makanan yang tertinggal.

3. Mempertahakan hidrasi, mencegah pengeringan rongga mulut.

4. Merangsang saliva untuk menetralkan asam dan melindungi memebran mukosa.

5. Makanan pedas akan membuka lesi yang tlah disembuhakan, lesi yang terbuka akan diperburuk dengan garam, asam, akan menyebabakan nyeri.

6. Rokok akan mengeringkan dan mengiritasi membran mukosa oral

7. Menghambat proses infeksi

1. Edema, lesi mukosa oral dan tenggorok kering

2. Menebabakan rasa sakit dan sulit mengunyah atau menelan Mengurangi ras tidak nyaman, meningkatkan rasa sehat dan mencegah pembentukan asam yang dikaitkan denganpartikel makanan yang tertinggal.

3. Mempertahakan hidrasi, mencegah pengeringan rongga mulut.

4. Merangsang saliva untuk menetralkan asam dan melindungi memebran mukosa

5. Makanan pedas akan membuka lesi yang telah disembuhakan,lesi yang terbuka akan diperburuk dengan garam, asam, akan menyebabakan nyeri.

6. Rokok akan mengeringkan dan mengiritasi membran mukosa 7. Menghambat proses infeksi 


\section{Pelaksanaan}

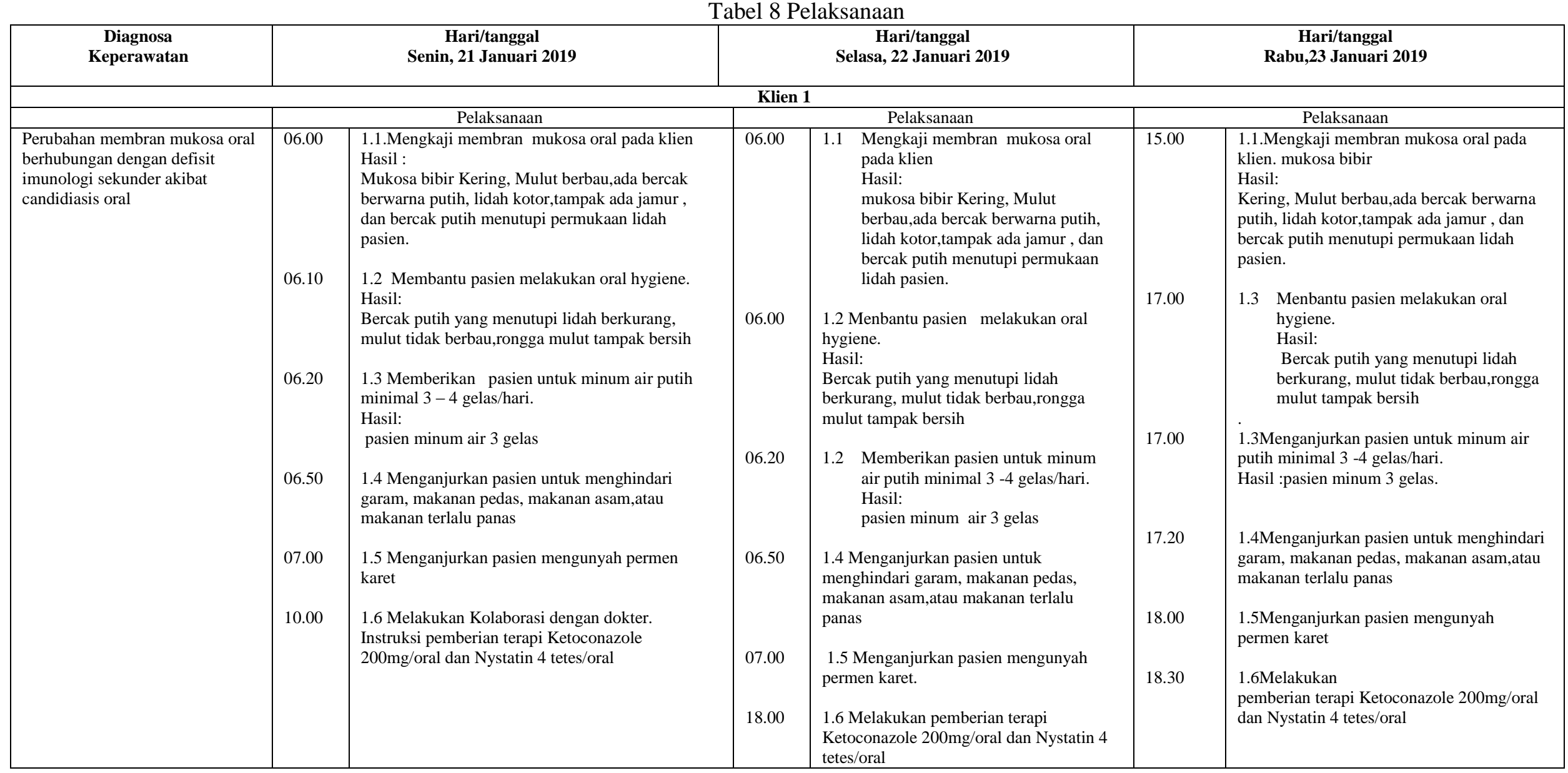




\begin{tabular}{|c|c|c|c|c|c|c|}
\hline $\begin{array}{l}\text { Diagnosa } \\
\text { Keperawatan }\end{array}$ & \multicolumn{2}{|r|}{$\begin{array}{c}\text { Hari/tanggal } \\
\text { Selasa, 22 Januari } 2019\end{array}$} & \multicolumn{2}{|r|}{$\begin{array}{c}\text { Hari/tanggal } \\
\text { Rabu, 23 Januari } 2019 \\
\end{array}$} & \multicolumn{2}{|r|}{$\begin{array}{c}\text { Hari/tanggal } \\
\text { Kamis, 24 Januari } 2019 \\
\end{array}$} \\
\hline \multicolumn{7}{|c|}{ Klien 2} \\
\hline & & Pelaksanaan & & Pelaksanaan & & Pelaksanaan \\
\hline \multirow[t]{7}{*}{$\begin{array}{l}\text { Perubahan membran mukosa oral } \\
\text { berhubungan dengan defisit } \\
\text { imunologi sekunder akibat } \\
\text { candidiasis oral }\end{array}$} & 07.00 & $\begin{array}{l}1.1 \text { Mengkaji membran mukosa oral pada } \\
\text { klien. } \\
\text { Hasil: } \\
\text { Mukosa bibir Kering, Mulut berbau,ada bercak } \\
\text { berwarna putih, lidah kotor, tampak ada jamur } \\
\text {, dan bercak putih menutupi permukaan lidah } \\
\text { pasien. }\end{array}$ & 07.00 & $\begin{array}{l}\text { 1.1Mengkaji membran mukosa oral pada } \\
\text { klien. } \\
\text { Hasil: } \\
\text { Mukosa bibir Kering, Mulut berbau,ada } \\
\text { bercak berwarna putih, lidah kotor,tampak } \\
\text { ada jamur, dan bercak putih menutupi } \\
\text { permukaan lidah pasien }\end{array}$ & 16.00 & $\begin{array}{l}\text { 1.1Mengkaji membran mukosa oral pada } \\
\text { klien. } \\
\text { Hasil: } \\
\text { Mukosa bibir Kering, Mulut berbau, ada } \\
\text { bercak berwarna putih, lidah kotor, tampak } \\
\text { ada jamur, dan bercak putih menutupi } \\
\text { permukaan lidah pasien }\end{array}$ \\
\hline & 07.10 & $\begin{array}{l}1.2 \text { Menbantu pasien melakukan oral hygiene. } \\
\text { Hasil: } \\
\text { Bercak putih yang menutupi lidah berkurang, } \\
\text { rongga mulut tampak bersih, mukosa bibir } \\
\text { lembab }\end{array}$ & 07.20 & $\begin{array}{l}1.2 \text { Menbantu pasien melakukan oral } \\
\text { hygiene. } \\
\text { Hasil: } \\
\text { bercak putih yang menutupi lidah } \\
\text { berkurang, rongga mulut tampak bersih, } \\
\text { mukosa bibir lembab }\end{array}$ & 17.00 & $\begin{array}{l}\text { 1.2Menbantu pasien melakukan oral hygiene } \\
\text { Hasil: } \\
\text { Bercak putih yang menutupi lidah } \\
\text { berkurang, rongga mulut tampak bersih, } \\
\text { mukosa bibir lembab }\end{array}$ \\
\hline & 07.20 & $\begin{array}{l}\text { 1.3Menganjurkan pasien untuk minum air } \\
\text { putih minimal } 3-4 \text { gelas/hari. } \\
\text { Hasil: } \\
\text { Pasien minum air } 3 \text { gelas }\end{array}$ & 08.20 & $\begin{array}{l}\text { 1.3Memberikan pasien untuk minum air } \\
\text { putih minimal } 3-4 \text { gelas/hari. } \\
\text { Hasil: } \\
\text { Pasien minum air } 3 \text { gelas }\end{array}$ & 18.00 & $\begin{array}{l}\text { 1.3Memberikan pasien untuk minum air } \\
\text { putih minimal } 3-4 \text { gelas/hari. } \\
\text { Hasil: } \\
\text { Pasien minum air } 3 \text { gelas }\end{array}$ \\
\hline & 07.50 & $\begin{array}{l}\text { 1.4 Menganjurkan pasien untuk menghindari } \\
\text { garam, makanan pedas, makanan asam,atau } \\
\text { makanan terlalu panas. }\end{array}$ & 08.50 & $\begin{array}{l}\text { 1.4Menganjurkan pasien untuk } \\
\text { menghindari garam, makanan pedas, } \\
\text { makanan asam,atau makanan terlalu panas }\end{array}$ & 18.20 & $\begin{array}{l}\text { 1.4Menganjurkan pasien untuk menghindari } \\
\text { garam, makanan pedas, makanan asam,atau } \\
\text { makanan terlalu panas. }\end{array}$ \\
\hline & 08.00 & $\begin{array}{l}\text { 1.5 Menganjurkan pasien mengunyah permen } \\
\text { karet }\end{array}$ & 09.00 & 1.5Menganjurkan pasien mengunyah & 18.10 & $\begin{array}{l}\text { 1.5Menganjurkan pasien mengunyah permen } \\
\text { karet }\end{array}$ \\
\hline & 08.10 & 1.6 Menganjurkan pasien tidak merokok & 0010 & 16 Mencaniurkan nacien tidak merokok & 18.15 & 1.6 Menganjurkan pasien tidak merokok \\
\hline & 10.00 & $\begin{array}{l}\text { 1.7 Melakukan Kolaborasi dengan dokter. } \\
\text { Instruksi pemberian terapi: Nystatin } 4 \\
\text { tetes/oral }\end{array}$ & 10.00 & $\begin{array}{l}1.7 \text { Melakukan pemberian terapi Nystatin } \\
4 \text { tetes/oral }\end{array}$ & 19.00 & $\begin{array}{l}1.7 \text { Melakukan pemberian terapi Nystatin } 4 \\
\text { tetes/oral }\end{array}$ \\
\hline
\end{tabular}




\section{Evaluasi}

\begin{tabular}{|c|c|c|}
\hline \multicolumn{3}{|r|}{ Tabel 9 Evaluasi } \\
\hline Diagnosa & Hari ke -1: Senin, 21 Januari 2019 & Hari ke - 2: Selasa, 22 Januari 2019 \\
\hline & & Klien 1 \\
\hline $\begin{array}{l}\text { Perubahan membran mukosa } \\
\text { oral berhubungan dengan } \\
\text { defisit imunologi sekunder } \\
\text { akibat candidiasis oral }\end{array}$ & $\begin{array}{l}\text { S: Jam } 14.30 \\
\text { Pasien mengatakan tidak ada napsu makan, ada luka } \\
\text { didalam mulut dan sakit saat menelan,Lidah terasa tebal, } \\
\text { setiap kali makan mual - muntah. } \\
\text { O: Pasien tampak kurus, pucat, hanya berbaring ditempat } \\
\text { tidur, mukosa bibir Kering, Mulut berbau, ada bercak } \\
\text { berwarna putih, lidah kotor, tampak ada jamur, dan } \\
\text { bercak putih menutupi permukaan lidah pasien. } \\
\text { Terpasang IVFD } 30 \text { tetes } / \text { menit. N: } 87 \text { x/menit; RR: } 20 \\
\text { x/menit; TD: } 110 / 70 \mathrm{mmHg} \text { Suhu } 37^{\circ} \mathrm{C} \text {. Hasil } \\
\text { Laboratorium tanggal } 22 \mathrm{Januari} 2019 \text { Pemeriksaan } \\
\text { Serologi. HIV : Positive. } \\
\text { A : Masalah Perubahan membran mukosa oral belum } \\
\text { teratasi. } \\
\text { P : Intervensi 1- } 7 \text { dilanjutkan }\end{array}$ & $\begin{array}{l}\text { S : Jam } 14.30 \\
\text { Pasien mengatakan napsu makan masih kurang,ada luka } \\
\text { dalm mulut, sakit saat menelan, lidah masih terasa tebal, } \\
\text { setiap makan mual -muntah. } \\
\text { O:Pasien tampak kurus, pucat, hanya berbaring ditempat } \\
\text { tidur, mukosa bibir kering, bau mulut berkurang, ada } \\
\text { bercak berwarna putih di lidah dan mulut berkurang, } \\
\text { lidah masih tampak kotor, masih ada bercak putih } \\
\text { menutupi permukaan lidah pasien. Terpasang IVFD RL } \\
20 \text { tetes/menit. Suhu : } 37^{\circ} \mathrm{C} ; \text { Nadi }: 80 \mathrm{x} / \text { menit; RR: } 20 \\
\text { x/menit. TD : } 110 / 70 \mathrm{mmHg} \text {. } \\
\text { A: Masalah perubahan membran mukosa oral teratasi } \\
\text { sebagian } \\
\text { P: Intervensi } 1,2,3,4 \text {, dan } 6 \text { dilanjutkan, no } 5 \text { dan } 7 \\
\text { dihentikan }\end{array}$ \\
\hline
\end{tabular}

Hari ke - 3: Rabu, 23 Januari 2019

S : Jam 21.30

Pasien mengatakan napsu makan mulai membaik, luka dalam mulut mulai membaik, sakit saat menelan berkurang, lidah teras tebal berkurang, mual -muntah berkuarang.

$\mathbf{O}$ : Pasien tampak kurus, pasien mulai duduk, mukosa bibir tampak lembab, bau mulut berkurang, bercak putih di lidah dan mulut berkurang, Terpasang IVFD RL 20 tetes /menit. Suhu : $37^{\circ} \mathrm{C}$; Nadi : $80 \mathrm{x} / \mathrm{menit}$; RR: $20 \mathrm{x} / \mathrm{menit}$. TD : 110/70 $\mathrm{mmHg}$.

A: Masalah perubahan membran mukosa teratasi sebagian.

P : Intervensi 1, 2, 3, 4 dan 6 dipertahankan.

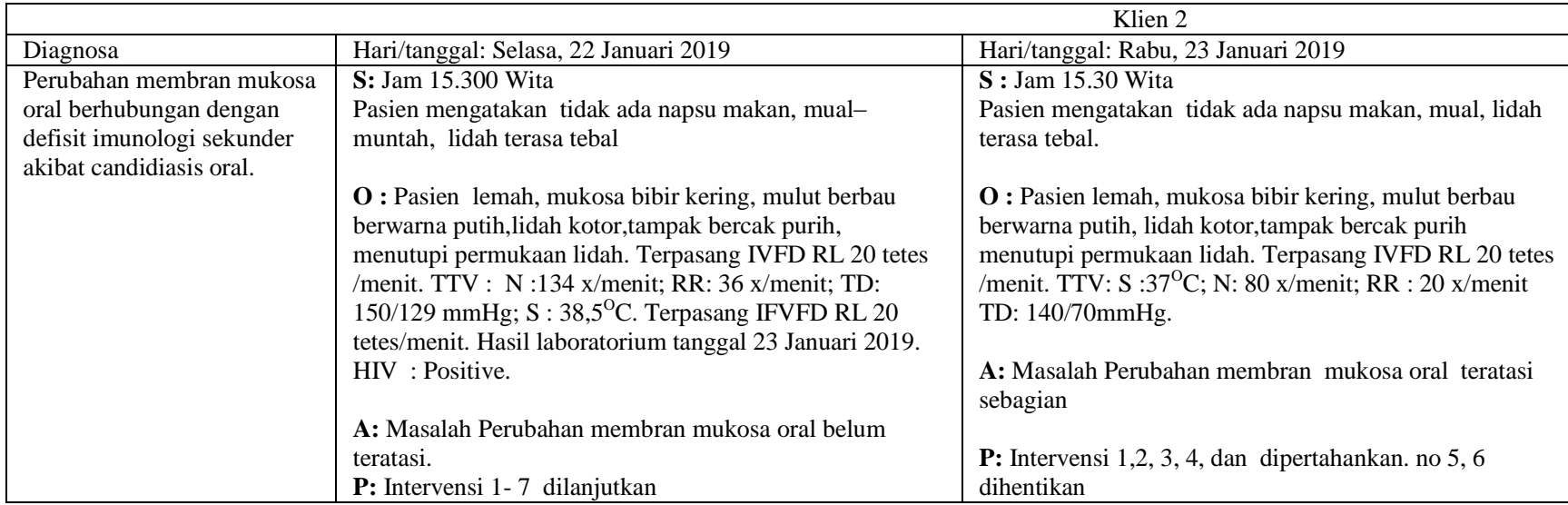

\section{Hari/tanggal: Kamis, 24 Januari 2019}

S :Jam 22.00Wita

Pasien mengatakan napsu makan mulai membaik,mual, lidah terasa tebal berkurang

O : Pasien lemah, mukosa bibir lembab, mulut berbau berwarna merah muda,lidah kotor berkurang,tampak bercak putih menutupi permukaan lidah brkuran,Terpasang IVFD RL 20 tetes /menit. TTV: Suhu $: 37,5^{\circ} \mathrm{C}$; Nadi : $87 \mathrm{x} / \mathrm{menit}$; RR $\quad: 20 \mathrm{x} / \mathrm{menit}$ TD $: 140 / 70 \mathrm{mmHg}$.

A: Masalah Perubahan membran mukosa oral teratasi sebagian

P: Intervensi 1,2, 3, 4,dan 7 dipertahankan 


\section{PEMBAHASAN}

Pengkajian pada klien 1 dan klien 2 ditemukan tidak ada napsu makan, ada luka didalam mulut dan sakit saat menelan, Lidah terasa tebal, setiap kali makan mual - muntah.Pasien tampak kurus,pucat,hanya berbaring ditempat tidur, mukosa bibir Kering, Mulut berbau,ada bercak berwarna putih, lidah kotor,tampak ada jamur, dan bercak putih menutupi permukaan lidah pasien.semua aktivitas dibantu oleh keluarga.Nadi:87x/menit,RR: 20x/menit, Tekanan Darah : 110/70mmHg, Suhu: $37,5^{\circ} \mathrm{C}$. tanda - tanda vital: Suhu: $38,5^{\circ} \mathrm{C}$, Nadi : 134x/menit, RR: 36x/menit, Tekanan Darah : 150/129 mmHg. Menurut Doengoes (2000: 833 836), hal - hal yang perlu dikaji pada pasien HIV/AIDS antara lain : Aktivitas/Istirahat, Sirkulasi, Integritas, eliminasi, makanan/cairan, kemampuan mengenali makanan, mual muntah,disfagia,nyeri retroternal saat menelan penurunan berat badan, perawakan kurus,menurunnya lemak,subkutan/massa otot, turgor kulit buruk, lesi pada ronnga mulut, adanya selaput putih dan perubahan warna, kesehatan gigi/gusi yang buruk oedema hygiene, neuro sensori, nyeri/ nyaman, pernapasan, keamanan, seksualitas, interaksi sosial, penyuluhan/ pembelajaran. Berdasarkan fakta dan teori diatas dapat dijelaskan tidak ada perbedaan yang bermakna antara kedua klien.Sehingga dalam melakukan pengkajian keperawatan perubahan membran mukosa oral penulis berpedoman pada teori yang dikemukan oleh Doengoes (2000)

Diagnosa keperawatan: pada kasus klien 1 dan klien 2 diagnosa yang ditemukan yaitu Perubahan membran mukosa oral berhubungan dengan defisit imunologi sekunder akibat candidiasis oral. Yang ditandai dengan klien 1 mengatakan tidak ada napsu makan, ada luka didalam mulut dan sakit saat menelan, Lidah terasa tebal, setiap kali makan mual - muntah. Pasien tampak kurus,pucat,hanya berbaring ditempat tidur,mukosa bibir Kering, Mulut berbau,ada bercak berwarna putih, lidah kotor,tampak ada jamur, dan bercak putih menutupi permukaan lidah pasien.semua aktivitas dibantu oleh keluarga.Nadi:87x/menit,RR: 20x/menit, Tekanan Darah : 110/70mmHg, Suhu: $37,5^{\circ} \mathrm{C}$, Klien 2 Suhu: $38,5^{\circ} \mathrm{C}$, Nadi : $134 \mathrm{x} / \mathrm{menit}$, RR: 36x/menit, Tekanan Darah : 150/129 mmHg. Menurut Doengoes (2000:838 -856), salah satu diagnosa keperawatan yang muncul pada pasien dengan HIV/AIDS, yaitu perubahan membran mukosa oral berhubungan dengan defisit imunologi sekunder akibat candidiasis oral. Perubahan membran mukosa oral merupakan infeksi opurtunistik yang sangat umum pada orang yang terinfeksi HIV dan orang yang sistem kekebalan imun tubuhnya menurun (Zakaria, 2016).
Leukoplakia yang ditandai dengan lesi putih rongga mulut, hanya saja tidak termasuk dalam lesi praganas. (Rangkuti, 2007). Penyebab dari perubahan membran mukosa oral adalah jamur spesies candida albicans (Siregar, 2015). Berdasarkan fakta dan teori defisitimunologi sekunder akibat candidiasis oral, maka dapat menimbulkan perubahan membran mukosa oral. Pernyatan ini didukung oleh teori Zakari (2016). Sehingga tidak ada perbedaan yang bermakna antara kedua klien.

Perencanaan: Pada kasus klien 1 dan klien 2 diagnosa yang ditegakan adalah Perubahan memebran mukosa oral berhubungan dengan defisit imunologi akibat candidiasis oral. Perubahan Membran Mukosa oral berhubungan dengan defisit imunologi sekunder akibat candidiasis oral. Goal : membran mukosa oral kembali utuh selama dalam perawatan 3 x 24 jam. Objektif: Setelah dilakukan tindakan keperawatan selama 3 x 24 jam diharapkan perubahan membran mukosa oral kembali utuh dengan kriteria hasil : Bercak - cak putih dalam mulut dan lidah berkurang, Mulut tidak berbau, Membran mukosa oral merah muda dan lembab, Jamur dalam mulut berkurang, TTV dalam batas normal, TD : $110-130 / 70 \mathrm{mmHg}$ Nadi: $60-100$ $\mathrm{x} / \mathrm{menit}$, Suhu : $36,5^{\circ} \mathrm{C}-37,5^{\circ} \mathrm{C}$, RR : $16-24$ $\mathrm{x} / \mathrm{menit}$. Intervensi yang dibuat antara lain sebagai berikut : Kaji membran mukosa atau catat seluruh lesi oral.Perhatikan keluhan nyeri,bengkak, sulit mengunyah atau menelan,, berikan perawatan oral setiap hari dan setelah makan, gunakan sikat gigi yang halus, motivasi pemasukan oral sedikit $2.500 \mathrm{ml} /$ hari, anjurkan mengunyah permen karet atau permen yang tidak mengandung gula, anjurkan pasien untuk menghindari garam, pedas, asam. tawarkan makanan yang dingin dan segar, motivasi pasien tidak merokok, kolaborasi obat - obatan sesuai instruksi dokter, antijamur, antimikroba. Menurut Doengoes (2000) perencanan pada klien dengan HIV/AIDS,Kaji membran mukosa atau catat seluruh lesi oral.Perhatikan keluhan nyeri,bengkak, sulit mengunyah atau menelan,, berikan perawatan oral setiap hari dan setelah makan, gunakan sikat gigi yang halus, motivasi pemasukan oral sedikit $2.500 \mathrm{ml} / \mathrm{hari}$, anjurkan mengunyah permen karet atau permen yang tidak mengandung gula, anjurkan pasien untuk menghindari garam, pedas, asam. tawarkan makanan yang dingin dan segar, motivasi pasien tidak merokok, kolaborasi obat -obatan sesuai instruksi dokter, antijamur, anti mikroba. Berdasarkan fakta dan teori pada klien 1 dan klien 2 ditemukan ada perbedaan rencana yang diberikan pada kedua klien, yaitu pada klien 1 terdapat 6 (enam) rencana sedangkan pada klien 2 terdapat 7 (tujuh) rencana. 
Implementasi keperawatan: Pada kasus klien 1 dan klien 2 tindakan yang diberikan untuk klien HIV/AIDS dengan diagnosa perubahan membran mukosa oral berhubungan dengan defisit imunologi akibat candidiasis oral: Mengkaji membran mukosa oral pada klien. mukosa bibir Kering, Mulut berbau,ada bercak berwarna putih, lidah kotor, tampak ada jamur, dan bercak putih menutupi permukaan lidah pasien, Mengukur tanda - tanda vital: Suhu $: 37,5^{\circ} \mathrm{C}$, Nadi : $87 \mathrm{x} /$ menit, RR : $20 \mathrm{x} / \mathrm{menit} \mathrm{TD}: 110 / 70 \mathrm{mmHg}$, Menbantu pasien melakukan oral hygiene mengunakan air hangat dan sehelai kain tipis dengan cara kain dicelupkan pada air hangat kemudian digunakan untuk membersihkan rongga mulut dan lidah pasien, dilanjutkan dengan menyikat gigi pasien dengan mengunakan pasta dan memakai sikat gigi yang halus. Hingga passien merasa segar, Menganjurkan pasien untuk minum air putih minimal $3-4$ gelas /hari, Menganjurkan pasien untuk menghindari garam, makanan pedas, makanan asam,atau makanan terlalu panas, Melakukan Kolaborasi dengan dokter. Instruksi pemberian terapi Ketoconazole 200mg/oral dan Nystatin 4 tetes/oral. Pengobatan ini sebaiknya dipantau dengan ketat karena masih terdapat pasien ODHA yang lalai minum obat atau tidak patuh minum obat yang sudah diresepkan (Tae et al., 2019). Menurut Nursalam (2008) tujuan dari pelaksanan adalah membantu pasien dalam mencapai tujuan yang telah ditetapkan yang mencakup peningkatan, pencegahan penyakit, pemulihan kesehatan dan menfasilitasi koping. Masih banyak ditmeukan pasien ODHA yang mengalami diskriminasi dan stigmatisasi (Berek \& Bubu, 2019) sehingga agar pasien tidak semakin tertutup dan mengisolasi diri, maka sebaiknya sejak perawatan di rumah sakit sebaiknya pasien tidak boleh didiskriminasi. Pelaksanaan adalah inisiatif dari rencana untuk mencapai tujuan yang spesifik. Tahap pelaksanaan dimulai setelah rencana tindakan disusun dan ditujukan pada nursing ordes untuk membantu klien mencapai tujuan yang diharapakan. Oleh karena itu rencana tindakan yang spesifik dilaksanakan untuk memodifikasi faktor -faktor yang mempengaruhi masalah kesehatan klien. Tujuan dari pelaksanaan adalah membantu klien dalam mencapai tujuan yang ditetapkan, mencakup peningkatan kesehatan, pencegahan penyakit, pemulihan kesehatan, dan menfasilitasi koping. Berdasarkan fakta dan teori diatas dapat dijelaskan ada perbedaan pelaksanaan pada kedua klien, dimana klien 1 hanya 6 (enam) rencana yang dilakukan. Rencana motivasi klien untuk tidak merokok tidak dilakukan karena klien 1 adalah seorang perempuan yang tidak merokok.
Evaluasi keperawatan: pada kasus klien 1 dan klien 2 dilakukan sesuai dengan pendekatan SOAP,dan dillakukan selama 3 hari. Adapun komponen yang dievaluasi pada pasien adalah secara subjektif kedua pasien memiliki keluhan yang sama, Secara teori menurut Nursalam (2008) tujuan evaluasi adalah melihat kemampuan pasien dalam mencapai tujuan. Hal ini bisa dilaksanakan dengan mengadakan hubungan dengan pasien berdasarkan respon pasien terhadap tindakna keperawatan yang diberikan. Evaluasi adalah tindakn intelektual untuk melengkapi proses keperawatan yang menandakan seberapa jauh diagnosa keperawatan, rencana keperawatan, dan pelaksanaanya sudah berhasil dicapai. Melalui evaluasi memungkinkan peneliti memonitor kealpaan yang terjadi selama pengkajian, analisa, perencanaan, dan pelaksanaan (Nursalam 2001:135). Berdasarkan fakta dan teori didapatkan evaluasi yang dilakukan setelah 3 hari perawatan. Untuk melakukan evaluasi kriteria hasil adalah: bercak - cak putih dalam mulut dan lidah berkurang, mulut tidak berbau, membran mukosa oral merah muda dan lembab, jamur dalam mulut berkurang, TTV dalam batas normal, TD : 110 130/70 mmHg, Nadi: $60-100$ x/menit, Suhu : $36,5^{\mathrm{O}}$ C $-37,5^{\circ} \mathrm{C}, \mathrm{RR}: 16-24 \mathrm{x} / \mathrm{menit}$. Sehingga setelah perawatan selam 3 (tiga) hari masalah perubahan membran mukosa oral pada kedua klien teratasi sebagian. Hal ini disebabkan karena virus HIV masih dalam tubuh kedua klien sehingga infeksi opurtunistik masih ada. Sebelum pulang, pasien diberi penyuluhan tentang HIV/AIDS dan penyebarannya sebagainaya agar bisa menekan penularan serta tidak memperburuk kondisi pasien (Berek et al., 2018)

\section{KESIMPULAN}

Pengkajian yang dilakukan yang dilakukan pada kedua klien secara holistik. Selanjutnya Diagnosa keperawatan yang ditegakan pada kasus ini yaitu perubahan membran mukosa oral berhubungan dengan defisit imunologi akibat candidiasis oral. Rencana tindakan klien 1 dan klien 2 yang mengalami HIV/AIDS yang mengalami perubahan membran mukosa oral dilakukan sesuai keluhan yang ditunjukkan pasien. Implementasi mengacu pada rencana yang telah disusun. Dan evaluasi pada kasus klien 1 dan klien 2 dilakukan sesuai dengan pendekatan SOAP, dan dillakukan selama 3 hari.

\section{DAFTAR PUSTAKA}

Berek, P. A. L., Be, M. F., Rua, Y. M., \& Anugrahini, C. (2018). Hubungan Jenis Kelamin dan Umur Dengan Tingkat Pengetahuan Remaja Tentang HIV/AIDS di 
SMAN 3 Atambua, Nusa Tenggara Timur. Jurnal Sahabat Keperawatan, 1, 1-13. https://jurnal.unimor.ac.id/JSK/article/view/85

Berek, P. A. L., \& Bubu, W. (2019). Hubungan Antara Umur, Jenis Kelamin, Pendidikan dan Pekerjaan dengan STigmatisasi Terhadap Orang Dengan HIV/AIDS di RSUD Mgr. Gabriel Manek, SVD Atambua. Jurnal Sahabat Keperawatan, 2(1), 36-44. https://jurnal.unimor.ac.id//JSK

Benjamin, W. 2011. Intisari Mikrobiologi dan Imunologi. Jakarta: EGC

Doenges,. E, dkk. 1999. Rencana Asuhan Keperawatan Pedoman untuk Perencanaan dan Pendokumentasian Perawatan Pasien. Jakarta: EGC

Fauk, N. K., Sukmawati, A. S., Berek, P. A. L., Ernawati, Kristanti, E., Wardojo, S. S. I., Cahaya, I. B., \& Mwanri, L. (2018). Barriers to HIV testing among male clients of female sex workers in Indonesia. International Journal for Equity in Health, 17(1), 1-10. https://doi.org/10.1186/s12939-018-0782-4

Huda, A \& Kusuma, H. 2016. Asuhan Keperawatan Praktis Berdasarkan Penerapan Diagnosa Nanda, NIC, NOC Dalam Berbagai Kamus. Jogjakarta: Mediaction

Ibrahim, K., Rahayuwati, L., Nurmalisa, B, E., and Fitri, SUR. 2018. Hubungan antara Fatique, Jumlah CD4 dan Kadar Hemoglobin pada Pasien yang Terinfeksi Human Immunodeficiency Virus. Jurnal Keperawatan Padjajaran.

Kambu, Y., Waluyo, A and Kuntarti, K. 2016. Umur Orang Dengan HIV AIDS (ODHA) Berhubungan dengan Tindakan Pencegahan Penularan HIV. Jurnal Keperawatan Indonesia, 19(3), pp. 200207
Leepel, L. A., Hidayat, R., Puspitawati, R., and Bahtiar, B.M. 2009. Efek Penambahan Glukosa pada Saburoud Broth Terhadap Pertumbuhan Candida Albicans (Uji In Vitro), Journal of Dentistry Indonesia, 6(1), pp 58-63

MauBili, dkk. 2008. HIV/AIDS, PMS dan Masyarakat Kita. Kupang: Gita Kasih

Muttaqin, A dan Kumala, S. 2012. Asuhan Keperawatan Gangguan Sistem Integumen. Jakarta: Salemba Medika

Masyhuri, I. 2015. Gambaran Pengetahuan, Sikap dan Tindakan Mahasiswa Profesi Kedokteran Gigi Tentang HIV/AIDS di Rumah Sakit Gigi dan Mulut Universitas Muhammadiyah Yogyakarta (Doctoral Dissertation, Fakultas Kedokteran dan Ilmu Kesehatan Universitas Muhammadiyah Yogyakarta)

Nursalam, M. 2008. Proses dan Dokumentasi Keperawatan Konsep dan Praktik. Jakarta: Salemba Medika

Ramayanti, S. 2013. Manifestasi Oral Pada Pasien Infeksi Virus HIV/AIDS. Andalas Dental Jornal, $1(1)$

Tae, F., Riwoerohi, E. D. F., \& Berek, P. A. L. (2019). Gambaran Kepatuhan Minum Obat Antiretroviral Pada Orang Dengan HIV/AIDS di Puskesmas Wedomu Kabupaten Belu Nusa Tenggara Timur. In Jurnal Sahabat Keperawatan (Vol. 2, Issue 1). https://jurnal.unimor.ac.id/JSK

Waluyo, A., Sukmarini, L., and Rosakawati, R. 2006. Persepsi Perawat dan Keluarga Pasien Tentang Pengetahuan yang Diperlukan untuk Merawat ODHA di Rumah Sakit dan di Rumah. Jurnal Keperawatan Indonesia, 10(1), pp. 16-23 